\title{
Evaluation of Anti-tumour effects of Withaferin A Using Molecular Markers in a Rat Model of Mammary Carcinogenesis
}

\author{
K. Pratheepa ${ }^{1 *}$, K. Vijayarani ${ }^{2}$, C. Balachandran ${ }^{1}$, R. Sridhar ${ }^{1}$ and K. Vijay ${ }^{3}$ \\ ${ }^{1}$ Department of Veterinary Pathology, ${ }^{2}$ Department of Bioinformatics \& ARIS cell, \\ ${ }^{3}$ Department of Veterinary Biochemistry, Madras Veterinary college, Chennai- 600 007, India \\ *Corresponding author
}

A B S T R A C T

Keywords

Bax, Bcl2, DMBA, Immuno-

histochemistry, Mammary tumour, p53, PCNA, RT-

PCR, Tamoxifen, Withaferin A

Article Info

Accepted:

10 June 2020

Available Online:

10 August 2020
The present study was designed to evaluate the anti-tumour potential of Withaferin $\mathrm{A}$ in DMBA (7,12-dimethylbenz[a]anthracene) induced rat mammary tumorigenesis. Seventy two female Sprague-Dawley rats were equally divided into control, DMBA, DMBA + tamoxifen (Standard drug) and DMBA + Withaferin A groups. DMBA (5 mg/rat/week/per os) at 4 weekly doses were used for tumour induction. Mammary tumours were collected on the $30^{\text {th }}, 75^{\text {th }}$ and $120^{\text {th }}$ day after the initial dose of DMBA administration. The expression of p53, bcl-2, bax and PCNA was analysed by immunohistochemistry and RT-PCR. Oral administration of Withaferin A $(16 \mathrm{mg} / \mathrm{kg}$ body weight/thrice a week/ per os) showed increased incidence of carcinomas by modulating markers of apoptosis (Bax, Bcl-2), cell survival (p53) and proliferation (PCNA) when compared to the standard drug tamoxifen $(100 \mu \mathrm{g} / \mathrm{kg}$ body weight/day/per os $)$.

\section{Introduction}

Cancer is one of the leading causes of death in humans all over the world. In developing countries breast cancer is the most prevalent cancer in women, representing $23 \%$ of the total cancer cases and it is the most leading cause of cancer death representing $14 \%$ of the cancer mortality (Jemal et al., 2011). In India, breast cancer is the second most common cancer after cervix, where 70,000 new cases of breast cancer are reported every year (Hortobagyi et al., 2005).

The etiology of breast cancer, although multifactorial, is predominantly hormonal, with increased lifetime exposure to endogenous and exogenous hormones playing a key role in neoplastic transformation (Yeole, 2008). 
Animal experimental model systems are used to study the human mammary carcinogenesis. Among these systems, chemically induced rat models are one of the most widely used models because the rat mammary gland shows a high susceptibility to neoplasms and these neoplasms closely mimic human breast disease. Moreover, rat model of tumouriogenesis has a short latency period and tumour tissues can be isolated at any time during tumouriogenesis.

Chemical carcinogens such as 7,12dimethylbenz[a]anthracene (DMBA), benz[a]pyrene (BP), 4-nitroquinoline-1-oxide and $\mathrm{N}$-nitroso-N-methylurea (NMU) are commonly employed to initiate and promote neoplastic transformation in experimental animals. However, the most commonly employed chemical carcinogen for inducing experimental carcinogenesis is DMBA (Letchoumy et al., 2006).

DMBA is a prototypic polycyclic aromatic hydrocarbons (PAHs) with carcinogenic and immunosuppressive effects in various species (Burchiel et al., 2005). DMBA mediated molecular, biochemical, genetic and histopathological changes were analogous to those observed in human cancers (Miyata et al., 2001). Administration of DMBA, in a single oral dose or in multiple doses, yields maximum mammary tumours. Among the various strains, outbred Sprague-Dawley (SD) rats are the most sensitive to DMBA. This model is well known for the development of multiple mammary tumours that are morphologically heterogenous and hormone dependent (Russo et al., 1990). Chemically induced mammary tumours are, in general, hormone dependent adenocarcinomas (Russo and Russo, 1996). DMBA- induced experimental carcinogenesis might therefore be used as an ideal model to study the chemopreventive potential of medicinal plants and their active constituents.
The synthetic non-steroidal antiestrogen, tamoxifen is the most common form of hormone therapy in patients suffering from hormone-sensitive breast cancer. It is a pioneering medicine (Jordan, 2003) used to treat all stages of breast cancer. It functions as an antagonist to estradiol (E2) in estrogen receptor (ER)-positive breast cancer. It should be used as a long term adjuvant therapy to suppress tumour recurrence (Jordan et al., 1979). Serum concentration of the drug and its metabolites vary with age, menopausal status and body mass index.

Side effects of tamoxifen treatment include development of tamoxifen resistance after 2-5 year of therapy, formation of tamoxifen-DNA adducts and induction of liver tumours in rodent life-term bioassays (Gallicchio et al., 2004), increased risk of menstrual abnormalities and bone loss in young premenopausal women, and increased risk of hot flashes, sexual dysfunction, cataracts, uterine cancer, and thromboembolic phenomena in premenopausal and postmenopausal women (Osborne, 1998).

Today there is much interest in natural products with anticancer activity. One such natural product is Withaferin A. Withaferin A is a steroidal lactone, mainly localized in the leaves (Gajbhiye et al., 2015) of the ayurvedic medicinal plant Withania somnifera (also known as Ashwaganda, Indian ginseng or Winter cherry) and has known to possess anticancer and radiosensitizing effects in human cancer cell lines and in animal cancer models without any noticeable systemic toxicity (Devi, 1996). For breast cancer, Withaferin A has been found to induce cell cycle arrest and apoptosis in vitro and inhibit tumour growth in mouse models with xenograft of human breast cancer cells (Stan et al., 2008). 
Hence, the present study was designed to evaluate the anti-tumour potential of Withaferin A by analyzing the molecular markers of apoptosis (Bax, Bcl-2), cell survival (p53) and proliferation (PCNA) using immunohistochemistry and RT-PCR in DMBA induced rat mammary carcinogenesis.

\section{Materials and Methods}

\section{Animals and diets}

All the experiments were carried out with female SD rats aged 38-days old, weighing between 65 to $130 \mathrm{~g}$, obtained from National Institute of Nutrition, Hyderabad, India. The animals were housed three to a polycarbonate cage and provided food and water ad libidum. The animals were maintained in a controlled environment under standard conditions of temperature and humidity with an alternating $12 \mathrm{~h}$ light/dark cycle. The animals were maintained in accordance with CPCSEA guidelines and approved by ethical committee, Tamilnadu Veterinary and Animal Sciences university.

\section{Experimental design}

The rats were randomized into experimental and control groups and divided into four groups of 18 animals each based on their body weight $(\mathrm{g})$. At $43^{\text {rd }}$ day of age, the rats in group 1 animals received basal diet and served as control. Group 2 animals received four weekly doses of DMBA (Sigma Aldrich Inc., St. Louis, USA) at the dose rate of 5 $\mathrm{mg} / \mathrm{rat} /$ week dissolved in olive oil by intragastric intubation. From the day of first dosing of DMBA, group 3 animals (DMBA+tamoxifen) was administered with tamoxifen (Khandelwal Laboratories Pvt. Ltd., Mumbai, India) at a dose rate of 100 $\mu \mathrm{g} / \mathrm{kg}$ body weight/day/per os dissolved in gingelly oil and group 4 animals $(\mathrm{DMBA}+$ Withaferin $\mathrm{A})$ received Withaferin
A (as gratis from Nutricon Bioscience Pvt. Ltd., Tamil Nadu, India) dissolved in PBS $(\mathrm{pH} 7.4)$ and given at the dose rate of 16 $\mathrm{mg} / \mathrm{kg}$ body weight/thrice a week/ per os till the end of study. The experiment was terminated at the end of 120 days and all animals were sacrificed in carbondioxide chamber after an overnight fast. A detailed post mortem was conducted on sacrificed rats. All the internal organs were examined for any evidence of metastasis. Gross pathology of the mammary tumour was recorded. Mammary tumour tissues were collected and distributed to various experiment. A portion of tumour samples was immediately stored at - $80^{\circ} \mathrm{C}$. The remaining mammary tumour samples were fixed in $10 \%$ neutral-buffered formalin and embedded in paraffin wax for histopathological and immunohistochemical studies. All the paraffin embedded tissue sections were screened and mammary tumours were classified histologically according to the criteria outlined by Mann et al., (1996) and Russo and Russo (2000). Representative blocks in benign and malignant tumour were selected for immunohistochemistry.

\section{Immunohistochemistry}

Three to four micrometer thin sections were mounted on polylysine-coated glass slides. Tissue sections were processed (Vinodhini et $a l ., 2009)$ and incubated with primary mouse monoclonal antibodies (1:100 dilutions) against Bcl-2, p53 and PCNA and rabbit polyclonal antibodies (1:100 dilutions) against Bax at room temperature for one hour. The slides were rinsed in PBS and incubated with horseradish peroxidase polymer based secondary antibody (Primary and secondary antibodies were obtained from M/s Biogenex USA). The brown colour immunoprecipitate was visualized by treating slides with 3,3 'diaminobenzidine. The sections were then counterstained with hematoxylin and 
examined under Olympus BX-51 microscope attached with image analyzer system (Image Proplus 5.1).

\section{Extraction of RNA}

Total RNA from the mammary gland tissues was extracted using Trizol reagent (Chomczynski and Sacchi, 1987). The purity and concentration of the RNA samples were measured at A280/260 by using NanoDrop ${ }^{\mathrm{TM}}$ 1000 spectrophotometer. In brief, $100 \mathrm{mg}$ of tumour tissue was homogenized using $1 \mathrm{~mL}$ of Trizol reagent. The homogenate was then treated with $250 \mu \mathrm{L}$ of chloroform and shook vigorously. The mixture was then centrifuged at $13,000 \mathrm{rpm}$ for $10 \mathrm{~min}$ at $4^{\circ} \mathrm{C}$. The aqueous phase was carefully pipetted out and equal volume of isopropanol was added, centrifuged at $13,000 \mathrm{rpm}$ for $10 \mathrm{~min}$ at $4{ }^{\circ} \mathrm{C}$. The supernatant was discarded gently and the precipitated RNA was rinsed twice with 400 $\mu \mathrm{L}$ of $75 \%$ ethanol and dried in air. RNA was resuspended in $20 \mu \mathrm{L}$ of DEPC treated water at a final concentration of $1 \mu \mathrm{g} / \mu \mathrm{L}$ and stored at $-80^{\circ} \mathrm{C}$ for further use.

\section{Reverse Transcriptase (RT) reaction: cDNA synthesis}

Isolated total RNA $(2 \mu \mathrm{L})$ was reversetranscribed to cDNA in a reaction mixture containing $4 \mu \mathrm{L}$ of $5 \mathrm{x}$ reaction buffer, $2 \mu \mathrm{L}$ of dNTPs mixture $(10 \mathrm{mM}), 1 \mu \mathrm{L}$ of RNase inhibitor, $1 \mu \mathrm{L}$ reverse transcriptase (RevertAid H Minus First Strand cDNA Synthesis kit from Thermoscientific, USA) and $1 \mu \mathrm{L}$ of oligo (dT) primer in a total volume of $20 \mu \mathrm{L}$. The reaction mixture was incubated at $25^{\circ} \mathrm{C}$ for $5 \mathrm{~min}, 42^{\circ} \mathrm{C}$ for $60 \mathrm{~min}$ and $70^{\circ} \mathrm{C}$ for $5 \mathrm{~min}$ and the synthesized cDNA was stored at $-80^{\circ} \mathrm{C}$ until further use.

\section{PCR amplification}

Details about the oligonucleotide primers (Sigma Aldrich Inc., St. Louis, USA) used for
PCR reactions are given in Table 1. The PCR amplification reaction mixture (in a final volume of $25 \mu \mathrm{L}$ ) contained $2 \mu \mathrm{L}$ of cDNA, 1 $\mu \mathrm{L}$ of forward primer, $1 \mu \mathrm{L}$ of reverse primer and $12.5 \mu \mathrm{L}$ of Master Mix Red (2.5x) (Ampliqon, Denmark). The PCR was carried out in a thermal cycler (Eppendorf). Thermocycling conditions for the primers are given in Table 2. Amplification products were analyzed by electrophoresis in a $1.5 \%$ agarose gel containing ethidium bromide $(1 \mu \mathrm{g} / \mathrm{mL})$ with $100 \mathrm{bp}$ DNA ladder. The PCR products were visualized using UV transilluminator for the presence of DNA band of specified size and image was photographed using gel documentation system (Biorad, USA).

\section{Results and Discussion}

The immunohistochemical cytoplasmic expression of Bax was observed in $90 \%$ of cells with higher intensity in DMBA group, mild to moderate intensity in Withaferin A group (Fig.1A) and poor expression was observed in tamoxifen group. Bcl-2 was expressed in $90 \%$ of cells with moderate intensity in Withaferin A group (Fig. 1B) and poor expression was noticed in the DMBA (Fig. 1C) and tamoxifen group.

In all groups, as the expression of Bax increased, the expression of Bcl-2 was decreased. This concurred with the findings of Krajewski et al., (1995) who reported that Bax expression was not related to ER status and was strongly associated with the Bcl-2 expression but the expression of $\mathrm{Bcl}-2$ was associated with the presence of ER (Gee et al., 1994; Leek et al., 1994) and the over expression of $\mathrm{Bcl}-2$ had been reported in several tumours including breast cancer ( He et al., 2003).

In Withaferin A group, there was over expression of $\mathrm{Bcl}-2$ and showed higher malignancy (confirmed histopathologically) and tumour frequency compared to standard 
drug tamoxifen which concurred with the findings of Thomadaki and Scorilas (2008) who reported that increased expression of Bcl-2 inhibited most kinds of programmed cell death and facilitated the survival of mammary tumour cells and reduced Bcl-2 mRNA expression inhibited mammary tumour growth (Zhang et al., 2010).

The immunohistochemical nuclear expression of p53 was negative in the luminal epithelial cells but positive in the fibroblast with moderate intensity in DMBA group (Fig. 1D), moderate intensity in tamoxifen group (Fig.1E) and negative/ mild expression in Withaferin A group.
The positive staining of p53 gene in tumour cells is reportedly indicative of p53 mutation (Rowley et al., 1998). In mammary carcinoma, mutations of p53 are associated with a more aggressive behavior and lower survival rate but the frequency of the p53 mutations was lower in mammary carcinoma in comparison with other solid tumours (Gasco et al., 2002). However, cancer associated mutant forms of p53 have long half life that promoted tumorigenesis and tumour aggressiveness (Sirvent et al., 2004) and in rodent model systems, p53 mutations in the pre-neoplastic lesions of the mammary gland are frequent (Jerry et al., 1993) though frank tumours develop from the cells that retain their wild-type p53 status (Kito et al., 1996).

Table.1 Oligonucleotide primers used for RT-PCR

\begin{tabular}{|c|c|c|c|c|c|}
\hline Gene & Primer & Sequence & $\begin{array}{l}\text { Length } \\
\text { (bp) }\end{array}$ & $\begin{array}{l}\text { Product } \\
\text { size (bp) }\end{array}$ & Reference \\
\hline \multirow[t]{2}{*}{$\begin{array}{l}\text { Bax } \\
\text { gene }\end{array}$} & Forward & $\begin{array}{l}\text { 5CCAAGCTGAGC } \\
\text { GAGTGTC }^{-3}\end{array}$ & 19 & \multirow{2}{*}{374} & \multirow{2}{*}{$\begin{array}{l}\text { Vinodhini et } \\
\text { al., (2009). }\end{array}$} \\
\hline & Reverse & $\begin{array}{l}\text { 5'- ACAAAGATGGTC } \\
\text { ACGGTCTGCC }{ }^{-3} \text { ' }\end{array}$ & 22 & & \\
\hline \multirow[t]{2}{*}{$\begin{array}{l}\text { Bcl-2 } \\
\text { gene }\end{array}$} & Forward & $\begin{array}{l}\text { 5'- TGCACCTGAC } \\
\text { GCCCTTCAC }^{-3}\end{array}$ & 19 & \multirow{2}{*}{293} & \multirow[t]{2}{*}{$\begin{array}{l}\text { Letchoumy et } \\
a l ., \text { (2007). }\end{array}$} \\
\hline & Reverse & $\begin{array}{l}\text { 5'AGACAGCCAGGA } \\
\text { GAAATCAAACAG }^{-3} \text {, }\end{array}$ & 24 & & \\
\hline \multirow[t]{2}{*}{$\begin{array}{l}\text { p53 } \\
\text { gene }\end{array}$} & Forward & $\begin{array}{l}\text { 5'- CTGAGGTTGGCT } \\
\text { CTGACTGTACCA } \\
\text { CCATCC }^{-3}\end{array}$ & 30 & \multirow[t]{2}{*}{370} & \multirow[t]{2}{*}{$\begin{array}{l}\text { Chen et al., } \\
\quad(2004)\end{array}$} \\
\hline & Reverse & $\begin{array}{l}\text { 5'- CTCATTCAGCTC } \\
\text { TCGGAACATCTC } \\
\text { GAAGCG }^{-3} \text { ' }\end{array}$ & 30 & & \\
\hline \multirow[t]{2}{*}{$\begin{array}{l}\text { PCNA } \\
\text { gene }\end{array}$} & Forward & $\begin{array}{l}\text { 5'-GCCСТCAAAGAC } \\
\text { CTCATCAA }^{-3} \text { ' }\end{array}$ & 20 & \multirow[t]{2}{*}{472} & \multirow[t]{2}{*}{$\begin{array}{l}\text { Vinodhini et } \\
\text { al., (2009) }\end{array}$} \\
\hline & Reverse & $\begin{array}{l}\text { 5'-GCTCCCCACTCG } \\
\text { CAGAAAAC }^{-3} \text { ' }\end{array}$ & 20 & & \\
\hline
\end{tabular}


Table.2 Thermocycling conditions for the primers

\begin{tabular}{|c|c|c|c|c|c|c|}
\hline Gene & $\begin{array}{c}\text { Initial } \\
\text { denaturation }\end{array}$ & Denaturation & $\begin{array}{c}\text { Primer } \\
\text { annealing }\end{array}$ & $\begin{array}{c}\text { Primer } \\
\text { extension }\end{array}$ & $\begin{array}{c}\text { Final } \\
\text { extension }\end{array}$ & $\begin{array}{c}\text { No. of } \\
\text { cycles }\end{array}$ \\
\hline Bax & $94^{\circ} \mathrm{C}, 5 \mathrm{~min}$ & $95^{\circ} \mathrm{C}, 1 \mathrm{~min}$ & $55^{\circ} \mathrm{C}, 1 \mathrm{~min}$ & $72^{\circ} \mathrm{C}, 1 \mathrm{~min}$ & $72^{\circ} \mathrm{C}, 7 \mathrm{~min}$ & 30 \\
\hline Bcl2 & $94^{\circ} \mathrm{C}, 5 \mathrm{~min}$ & $95^{\circ} \mathrm{C}, 1 \mathrm{~min}$ & $55^{\circ} \mathrm{C}, 1 \mathrm{~min}$ & $72^{\circ} \mathrm{C}, 1 \mathrm{~min}$ & $72^{\circ} \mathrm{C}, 7 \mathrm{~min}$ & 30 \\
\hline p53 & $94^{\circ} \mathrm{C}, 1 \mathrm{~min}$ & $94^{\circ} \mathrm{C}, 1 \mathrm{~min}$ & $55^{\circ} \mathrm{C}, 1 \mathrm{~min}$ & $72^{\circ} \mathrm{C}, 1 \mathrm{~min}$ & $72^{\circ} \mathrm{C}, 7 \mathrm{~min}$ & 30 \\
\hline PCNA & $95^{\circ} \mathrm{C}, 2 \mathrm{~min}$ & $95^{\circ} \mathrm{C}, 30 \mathrm{sec}$ & $60^{\circ} \mathrm{C}, 1 \mathrm{~min}$ & $72^{\circ} \mathrm{C}, 1 \mathrm{~min}$ & $72^{\circ} \mathrm{C}, 10 \mathrm{~min}$ & 35 \\
\hline
\end{tabular}

Fig.1 Immunohistochemistry (A) DMBA+ Withaferin A - IHC - Bax (DAB-Brown) - Positive cytoplasmic signals Bar=20 $\mu \mathrm{m}$, (B) DMBA+Withaferin A - IHC - Bcl2 (DAB-Brown) Positive cytoplasmic signals Bar $=20 \mu \mathrm{m},(\mathrm{C})$ DMBA - IHC - Bcl2 (DAB-Brown) - Positive cytoplasmic signals Bar=10 $\mu \mathrm{m}$, (D) DMBA - IHC - p53 (DAB-Brown) - Positive nuclear signals Bar=20 $\mu \mathrm{m}$. (E) DMBA+Tamoxifen- IHC - p53 (DAB-Brown) - Positive nuclear signals Bar $=10 \mu \mathrm{m}$. (F) DMBA+ Withaferin A - IHC - PCNA (DAB-Brown) Positive nuclear signals Bar $=50 \mu \mathrm{m}$

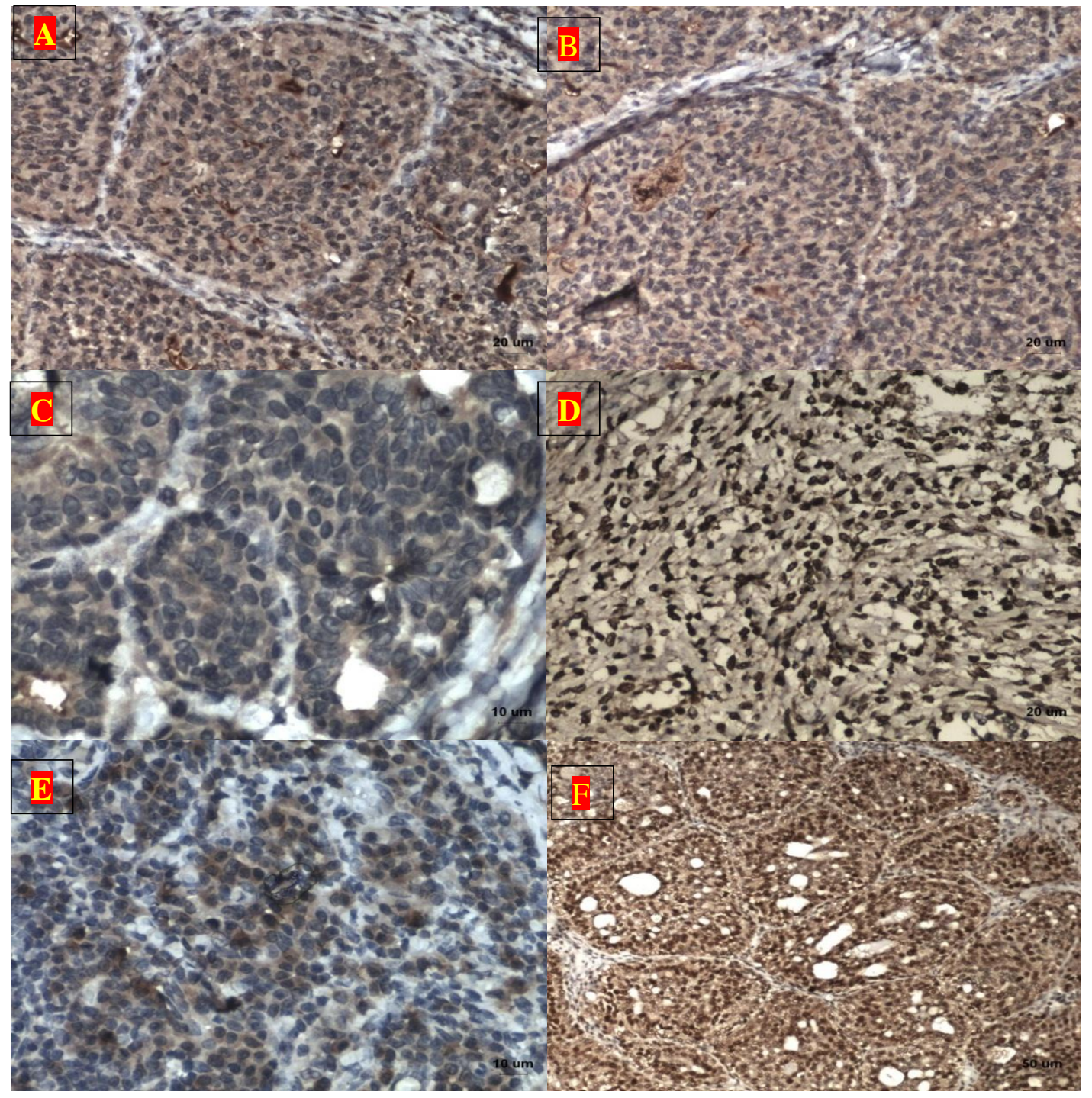


Fig.2 RT-PCR

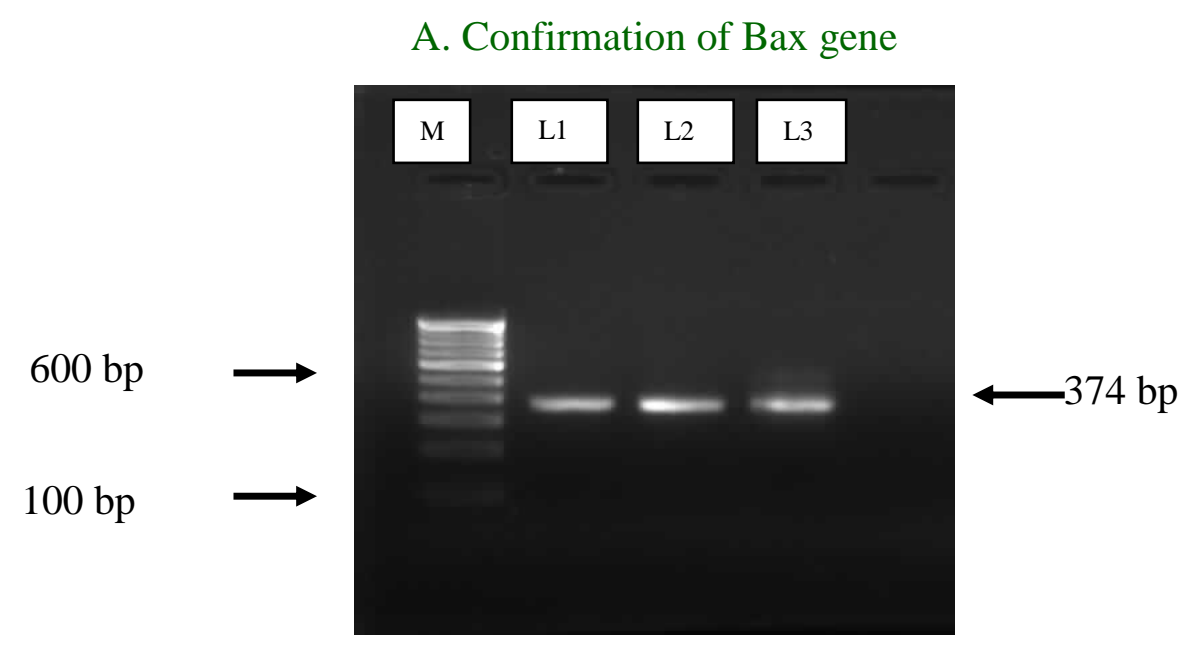

B. Confirmation of Bcl-2 gene

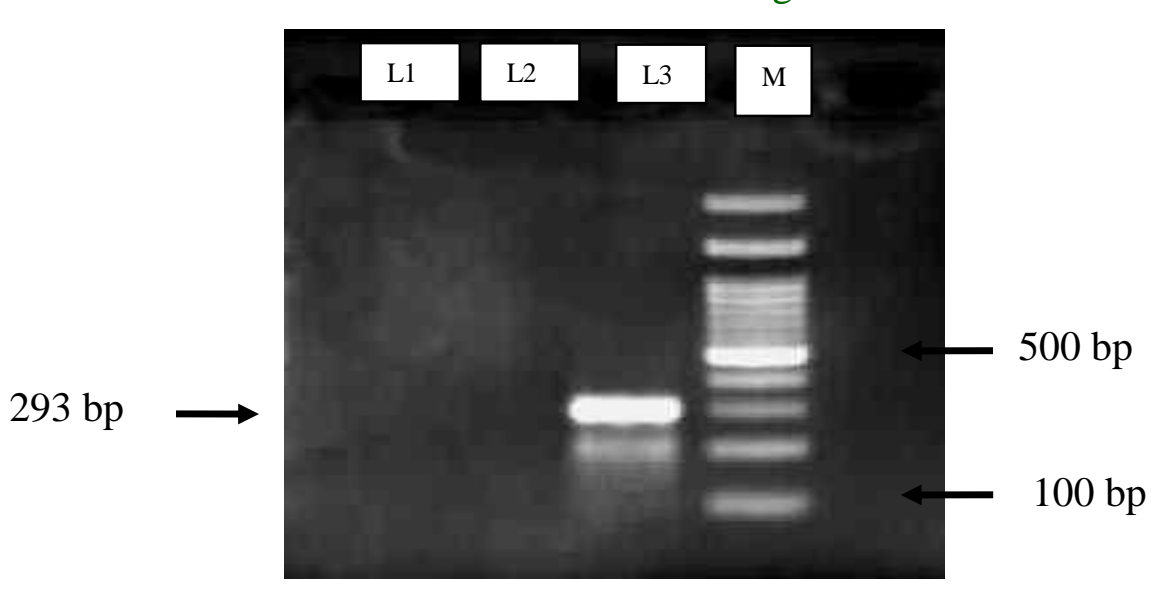

M- Marker, L- Lane, L1- DMBA, L2- DMBA+Tamoxifen, L3-DMBA+ Withaferin A

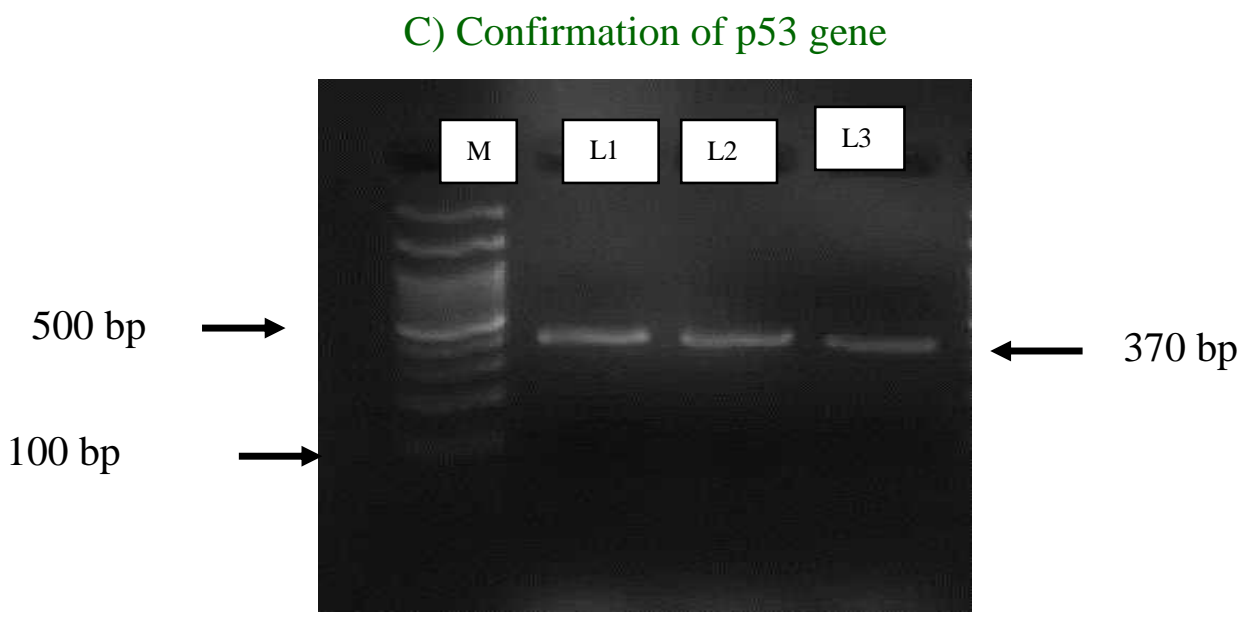




\section{D) Confirmation of PCNA gene}

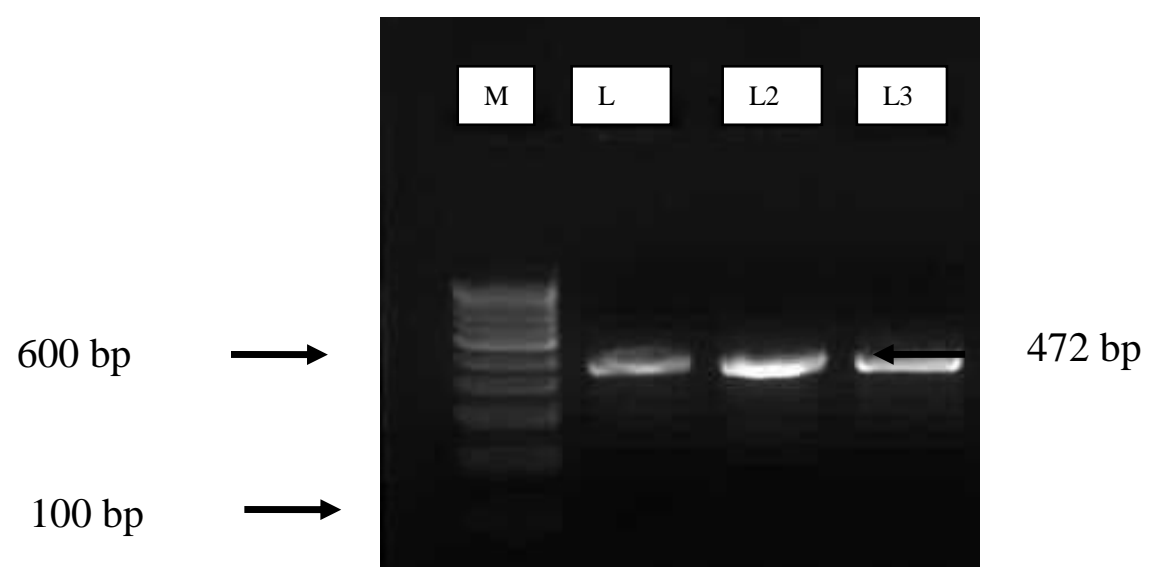

The immunohistochemical nuclear expression of PCNA was expressed in 75 to $90 \%$ of cells with higher intensity in DMBA, tamoxifen and Withaferin A groups (Fig.1F). PCNA expression has been considered to reflect the proliferation rate of tumour cells. Over expression of PCNA was noticed in various malignancies including breast cancer (Malkas et al., 2006) and the tumour with high index of PCNA had more aggressive growth, reoccurence, resulting in low survival rates (Li et al., 1996).

Goelet al., (2000) suggested that both p53 expression and PCNA are markers of poor differentiation in breast cancer and maximum p53 and PCNA positivity was observed in grade III tumors. Dysregulation of the balance between proliferation, differentiation and apoptosis in the normal mammary gland can lead to breast cancer development. The upregulation of cell proliferation as well as downregulation of apoptosis contributed to the accumulation of mutations, which lead to the subsequent development of breast cancer (Kumar et al., 2000; Tavassoli and Devilee, 2003).

The results of immunohistochemistry were further confirmed by RT-PCR. Bax, p53 and PCNA were expressed in the mammary tumours of DMBA, tamoxifen and Withaferin A groups, whereas Bcl-2 was expressed only in the Withaferin A group.

In conclusion, the study revealed that Withaferin $\mathrm{A}$ at the dose rate of $16 \mathrm{mg} / \mathrm{kg}$ body weight/thrice a week/per os for 16 weeks did not reduce mammary tumourburden compared to that of standard drug tamoxifen which was further confirmed by the molecular assay. Hence, a detailed investigation is required.

\section{Acknowledgement}

We sincerely thank and acknowledge the intense support provided by Late. Dr. S.M. Sakthivelan, M.V. Sc throughout the study. We also acknowledge M/s. Nutricon Bioscience Pvt. Ltd., Tamil Nadu, India for providing Withaferin A as gratis.

\section{References}

Burchiel, S.W., F.T. Lauer, S.L. Dunaway, J. Zawadki, J.D. McDonald and M.D. Reed, 2005. Hardwood smoke alters murine splenic $\mathrm{T}$ cell responses to mitogens following a 6-month whole body inhalation exposure. Toxicol. Appl. Pharmacol., 202: 229-236.

Chen, Y.K., S.S. Huse and L.M. Lin, 2004 
Differential expression of p53, p63 and p73 protein and mRNA for DMBA-induced hamster buccal-pouch squamous-cell carcinomas. Int. J. Exp. Pathol., 85: 97-104.

Chomczynski, P. and N, Sacchi, 1987. Single-step method of RNA isolation by acid guanidiniumthiocyanate-phenol-chloroform extraction. Anal. Biochem., 162: 156-159.

Devi, P.U., K. Akagi, V. Ostapenko, Y. Tanaka and T. Sugahara, 1996.Withaferin A: a new radiosensitizer from the medicinal plant Withania somnifera. Int. J. Radiat. Biol., 69: 193-197.

Gajbhiye, N.A., J. Makasanaand S. Kumar, 2015. Accumulation of three importanat bioactive compounds in different plant parts of Withania somnifera and its determination by the LC-ESI-MS-MS (MRM) method. $J$. Chromatogr. Sci., 53: 1749-1756.

Gallicchio, L., G. Lord, K. Tkaczuk, M. Danton, L.M. Lewis, C.K. Lim and J.A. Flaws, 2004.Association of tamoxifen (TAM) and TAM metabolite concentrations with selfreported side effects of TAM in women with breast cancer. Breast Cancer Res. Treat., 85: 89-97.

Gasco, M., S. Shami and T. Crook, 2002. The p53 pathway in breast cancer. Breast Cancer Res., 4: 70-76.

Gee, J.M., J.F. Robertson, I.O. Ellis, P. Willsher, R.A. McClelland, H.B. Hoyle, S.R. Kyme, P. Finlay, R.W. Blamey and R.I. Nicholson, 1994. Immunocytochemical localization of Bcl-2 protein in human breast cancers and its relationship to a series of prognostic markers and response to endocrine therapy. Int. J. Cancer, 59: 619-628.

Goel, M.M., R. Goel, A. Mehrotra, P. Nath, P.K. Agarwal, K. Singh and R. Mehrotra, 2000. Immunohistochemical localization and correlation of p53 and PCNA expression in breast carcinoma. Indian J. Exp. Biol., 38: 225-230.

He, Z., W.Y. Ma, T. Hashimoto, A.M. Bode, C.S. Yang and Z, Dong, 2003. Induction of apoptosis by caffeine is mediated by the p53, Bax and caspase 3 pathways. Cancer Res., 63: 4396-4401.

Hortobagyi, G.N., J.D.L.G. Salazar, K. Pritchard, D. Amadori, R. Haidinger, C.A. Hudis, H. Khaled, M.C. Liu, M. Martin, J.A.
O'Shaughnessy, Z.Z. Shen and K.S. Albain, 2005. The global breast cancer burdern: variations in epidemiology and survival. Clin. Breast Cancer, 6: 391-401.

Jemal, A., F. Bray, M.M. Center, J. Ferlay, E. Ward and D. Forman, 2011.Global cancer statistics. CA: A Cancer. J. Clin., 61: 69-90.

Jerry, D.J., M.A. Ozbun, F.S. Kittrell, D.P. Lane, D. Medina and J.S. Butel, 1993. Mutations in p53 are frequent in the preneoplastic stage of mouse mammary development. Cancer Res., 53: 3374-3381.

Jordan, V.C., 2003. Tamoxifen: A most unlikely pioneering medicine. Nat. Rev. Drug Discov., 2: 205-213.

Jordan, V.C., C.J. Dix and K.E. Allen, 1979.The effectiveness of long term tamoxifen treatment in a laboratory model for adjuvant hormone therapy of breast cancer. Adj. Ther. Cancer, 2: 19-26.

Kito, K., T. Kihana, A. Sugita, S. Murao, S. Akhei, M. Sato, M. Tachibana, S. Kimura and N. Udena, 1996. Incidence of p53 and Ha-ras gene mutations in chemically induced rat mammary carcinomas. Mol. Carcinogenesis, 17: 78-83.

Krajewski, S., C. Blomqvist, K. Franssila, M. Krajewska, V.M. Wasenius, E. Niskanen and J.C. Reed, 1995. Reduced expression of the proapoptotic gene Bax is associated with poor response rates to combined chemotherapy and shortened survival in women with metastatic breast adenocarcinoma. Cancer Res., 55: 44714478 .

Kumar, R., R.K. Vadlamudi and L. Adam, 2000. Apoptosis in mammary gland and cancer. Endocr. Relat. Cancer, 7: 257-269.

Leek, R.D., L. Kaklamanis, F. Pezzella, K.C. Gatter and A.L. Harris, 1994. Bcl-2 in normal human breast and carcinoma, association with oestrogen receptorpositive, epidermal growth factor receptornegative tumours and in situ cancer.Br. $J$. Cancer, 69: 135-139.

Letchoumy P.V., K.V.C. Mohan, R. Kumaraguruparan, Y. Hara and S. Nagini, 2006. Black tea polyphenols protect against 7,12-dimethylbenz[a]anthracene induced hamster buccal pouch carcinogenesis. Oncol. Res., 16: 167-178. 
Letchoumy, P.V., K.V. Poorna, C. Mohan, D. Prathiba, Y. Hara and S. Nagini, 2007.Comparative evaluation of antiproliferative, antiangiogenic and apoptosis inducing potential of black tea polyphenols in the hamster buccal pouch carcinogenesis. J. Carcinogenesis, 6: 19.

Li, J.Q., C.Q. Zhang, Y.Q. Zhang, Y.F. Yuan, M.S. Chen and G.H. Li, 1996.Immunohistochemical study of PCNA and p53 in primary liver cancer- an implication for prognosis and treatment. $J$. Exp. Clin .Cancer Res., 15: 77-80.

Malkas, L.H., B.S. Herbert, W. Abdel-Aziz, L.E. Dobrolecki, Y. Liu, B. Agarwal, D. Hoelz, S. Badve, L. Schnaper, R.J. Arnold, Y. Mechref and M.V. Novotny, 2006. A cancer associated PCNA expression in breast cancer has implications as a potential biomarker. Proc. Natl. Acad. Sci., 103: 19472-19477.

Mann, P.C., G.A. Boorman, L.O. Lollini, D.N. McMartin and D.G. Goodman, 1996.Proliferative lesions of the mammary gland in rats, IS-2. In: Guides for Toxicologic Pathology. pp. 1-7.

Miyata, M., M. Furukawa, K. Takahasi, F.J. Gonzalez and Y. Yamazoe, 2001. Mechanism of 7,12-dimethylbenz[a] anthracene induced immunotoxicity: role of metabolic activation at the target organ. Jpn J. Pharmacol., 86: 302-309.

Osborne, C.K., 1998. Tamoxifen in the treatment of breast cancer. N. Engl. J. Med., 339: 1609-1618.

Rowley, H., P. Sherrington, T.R. Helliwell, A. Kinsella and A.S. Jones, 1998.P53 expression and p53 gene mutation in oral cancer and dysplasia. Otolaryngol. Head Neck Surg., 118: 115-123.

Russo IH and Russo J. 1996. Mammary gland neoplasia in long-term rodent studies. Environ Health Perspect 104: 938-967.

Russo J and Russo IH. 2000. Atlas and histologic classification of tumours of the rat mammary gland. $J$ Mammary Gland Biol5:187-200.

Russo J, Gusterson BA, Rogers AE, Russo IH, Wellings SR and Zweiten MJV. 1990. Biology of disease: Comparative study of human and rat mammary tumorigenesis. Lab Invest 62: 224-278.

Stan, S.D., E.R. Hahm, R. Warin and S.V. Singh, 2008. Withaferin A causes FOXO3a and Bim dependent apoptosis and inhibits growth of human breast cancer cells in vivo. Cancer Res., 68: 7661-7669.

Tavassoli, F.A. and P. Devilee, 2003. Pathology and genetics of tumours of the breast and female genital organs. Lyon, France: IARC Press, Pp. 233-244.

Thomadaki, H. and A. Scorilas, 2008. Molecular profile of the Bcl-2 family of the apoptosis related genes in breast cancer cells after treatment with cytotoxic/cytostatic drugs. Connect Tissue Res., 49: 261-264.

Vinodhini, G., R.S. Murugan and S. Nagini, 2009. Evaluation of molecular markers in a rat model of mammary carcinogenesis. Oncol. Res., 17: 483-493.

Yeole, B.B., 2008. Trends in cancer incidence in female breast, cervix uteri and ovary in India. Asian Pac. J .Cancer Prev., 9: 119122.

\section{How to cite this article:}

Pratheepa, K., K. Vijayarani, C. Balachandran, R. Sridhar and Vijay, K. 2020. Evaluation of Anti-tumour effects of Withaferin A Using Molecular Markers in a Rat Model of Mammary Carcinogenesis. Int.J.Curr.Microbiol.App.Sci. 9(08): 263-272. doi: https://doi.org/10.20546/ijcmas.2020.908.031 